\title{
PAPER
}

\section{Sustainability and the anthropogenic alteration of evolutionary processes}

\author{
John Cairns, Jr.* \\ Department of Biology, Virginia Polytechnic Institute and State University, Blacksburg, Virginia 24061, USA
}

\begin{abstract}
Persuasive evidence indicates that Earth is now experiencing a major biotic crisis. Even if humankind ceases severe stress on natural systems, the crisis will probably disrupt the basic evolutionary processes that characterized the period preceding the agricultural and industrial revolutions. Proliferation of drug and pesticide resistant species and opportunistic species that thrive in human-dominated ecosystems will become increasingly common. The effect on humankind of altering basic evolutionary processes is uncertain because the understanding of these processes is not robust. The probable result will not be an environment as favorable to humans as the one that has existed for most of human history. Humans probably have altered the environment since Homo sapiens first appeared. However, only in the last two centuries has the degree and rate of change reached levels now considered by many people to be 'normal', even though the record shows they are not. Greatly improved technology has facilitated increased exploitation of natural resources to unsustainable levels. This exploitation, in turn, has led to exponential human population growth, which has depleted natural capital (living systems and the services they provide). Economic globalization has ensured that ecosystems far distant from consumers can be and are profitably exploited. Economic growth has become a universal mantra that is coupled with a conviction that such growth can continue indefinitely on a finite planet. A major paradigm shift is essential if sustainable use of the planet is to become a reality.
\end{abstract}

KEY WORDS: Evolution · Sustainability ethics · Destruction of natural capital · Human occupancy of Earth $\cdot$ Alteration of biosphere $\cdot$ Biotic extinctions $\cdot$ Economic globalization

Resale or republication not permitted without written consent of the publisher

... when we regard every production of nature as one which has had a history; when we contemplate every complex structure and instinct as the summing up of many contrivances, each useful to the possessor... how far more interesting, I speak from experience, will the study of natural history become!

Charles Darwin

(As quoted in Mayr 1977)

\section{ILLUSTRATIVE EXAMPLES OF HUMAN IMPACT ON THE ENVIRONMENT}

It is not the purpose of this discussion to provide an encyclopedic list of human impacts upon the environment (lists can be found in Brown et al. [2002] and Worldwatch Institute [2003a,b]), although some examples follow: fragmentation of ecosystems (e.g. Temple- ton et al. 2001), biotic impoverishment (e.g. Wilson 1992), disruption of the ozone layer, climate change from human production of greenhouse gases (e.g. Harte et al. 1992), acid rain, deforestation of old growth forests, disruption of the hydrologic cycle (e.g. National Research Council 1992), desertification (e.g. Eckholm 2000) due to overgrazing, excessive use of fossil water (underground aquifers, e.g. Postel \& 
Vickers 2004), sea level rise due to melting of glaciers ${ }^{1}$, soil erosion, declining ocean fisheries due to overharvesting, displacement of non-human species caused by exponential human population growth (e.g. Ehrlich \& Ehrlich 1990), damage by exposure to hazardous substances (e.g. Hoffman et al. 2003), introduction of alien species (e.g. Cairns \& Bidwell 1996), dramatic reduction of population size of many species, homogenization of biotas, and gross reduction of entire sectors of some biomes (e.g. Raup 1991). Unless human assaults on the environment are markedly diminished, the planet will be less habitable for both present and future generations of humans. What is lacking is major attention to the evolutionary consequences of these impacts.

\section{THE EVOLUTIONARY FUTURE IS UNCERTAIN}

Although scientists cannot reliably predict the species that will comprise ecosystems in the future, significant estimates can be offered about the ways in which human impacts will affect evolutionary processes. Although Myers gave attention to this issue as early as 1985, the first major attention occurred in 2000 at a US National Academy of Sciences Colloquium (Myers \& Knoll 2000). The temporal and spatial spans of evolutionary processes are impressive (e.g. Ehrlich 2000). One factor is certain-evolutionary processes will affect humankind's quest for sustainable use of the planet.

Of course, evolutionary future, in every sense, is always uncertain. However, uncertainty can be reduced if humankind attempts to maintain the conditions favorable to Homo sapiens. Most discussions of evolution are ex post facto. However, as Hardin (1999) notes, doing nothing is not a viable option because nothing never happens. Various statistical approaches can determine uncertainty; consequently, means exist for determining practices that are likely to reduce uncertainty, i.e. means for determining which practices are unsustainable and which show promise of being sustainable. The introduction to the National Academy of Sciences Colloquium edited by Myers and Knoll (2000) provides many illustrations of alterations of evolutionary practices that pose major obstacles to achieving sustainability because they have precipitated a biotic crisis.

Despite the critical importance of evolutionary processes, little attention has been given to them in publications on sustainable development, sustainability,

${ }^{1}$ See Lean G (2003) Melting ice 'will swamp capitals.' http://news.independent.co.uk/world/environment/story.jsp ?story $=470838$ and sustainable use of the planet, although some literature does exist (e.g. Cairns in press). However, the precautionary principle (e.g. Tickner 2003, p. xiii-xiv) states: 'When an activity raises threats of harm to human health or the environment, precautionary measures should be taken even if some cause and effect relationships are not fully established scientifically.' The 1998 Wingspread statement listed four central components of the principle: (1) taking preventative action in the face of uncertainty, (2) shifting burdens (of proof) onto proponents of potentially harmful activities, (3) exploring a wide range of alternatives to possibly harmful activities, and (4) increasing public participation in decision-making.

Some publications offer general guidance for reducing uncertainty and provide illustrations of attributes of both healthy and unhealthy ecosystems (e.g. National Research Council 2000) and trends that are likely to have both beneficial and adverse effects upon the environment (National Academy of Engineering 1997). The measurements of ecological footprint size for both individuals and societies (e.g. Wackernagel \& Rees 1996) provide a means of reducing human impact on Earth. Anderson (1998) provides examples of moving toward a sustainable enterprise that should markedly reduce the human impact on evolutionary processes. The National Academy of Engineering (1996) provides insights on the reduction of engineering impacts upon ecosystems. Hawken et al. (1999) provide practical evidence that corporations that reduce environmental impact can still generate satisfactory profits. Clearly, much can be done now to reduce human impact on evolutionary processes by ensuring the maintenance of healthy ecosystems and restoring damaged ecosystems (e.g. National Research Council 1992).

\section{EVOLUTIONARY ALTERATION OF HUMAN PROCESSES}

Ancient Greeks believed the Earth was a living goddess named Gaia (Lovelock 1972, 1979). The Gaia hypothesis supposes Earth to be alive (Lovelock 1988) and assumes that the atmosphere, the oceans, the climate, and the crust of Earth are regulated at a state comfortable for life because of the behavior of living organisms. Homo sapiens happens to be one beneficiary of the processes that produce the conditions favorable to Earth's present species. However, drastic alteration of the biosphere may result in a different set of conditions that still may be favorable to life, but not necessarily to $H$. sapiens. Thus, the Gaia hypothesis proposes that the biosphere is a highly integrated and self-organized or controlled system. However, individual organisms and complex ecological systems have 
important differences. Odum (1997) notes that the organism has set-point controls that maintain steady states at limits (homeostasis), while ecosystems have no set-point controls. In the ecosystem, positive and negative feedback maintains pulsing states at limits (homeorhesis). The absence of set-point controls persuades many scientists that ecosystems and the biosphere do not function as cybernetic systems, although most acknowledge that organisms play major roles in the control of the chemistry of the atmosphere and the oceans (e.g. Kerr 1988). In short, as Odum (1997) remarks, although the biosphere has exhibited the resilience and stability to recover in past ages, this history is no reason to be complacent about the resilience of present life-support systems. Clearly, human abuse of natural systems will have consequences that will affect the benign conditions humans take for granted.

\section{EARTH RIGHTS AND HUMAN RIGHTS}

How ironic that some nation-states, that proclaim the necessity for human rights, have the largest ecological footprint and, therefore, the greatest impact on the living Earth. Continued unsustainable practices that damage Earth's ecological life support system will markedly affect human society and even human survival. Compassion for Earth is inextricably linked to compassion for posterity (i.e. sustainable use of the planet) for which humankind has an ethical responsibility.

Both the journals and books of the Eco-Ethics International Union provide information on the obligation of the present generation to future generations. In addition, Agyeman et al. (2003) also discuss sustainable practices and posterity.

The Random House Dictionary, 2nd edition, defines abuse as 'to use wrongly or improperly'. In this context, abuse refers to any practice or action that damages ecological integrity. Of course, any use will have an impact, but, preferably, the use will be mutualistic. Using without abusing is the sine qua non of sustainability. Fuller was the first to recognize that events in higher levels of organization are never predicted by examining the lower levels of complexity (e.g. Gerber 2001). Gaia is the whole of which humankind is an influential part.

Peacock (1990) writes of a continuity over time that the home place provides, including a love that extends not only to humans but between other beings as well. Surely this concept of interconnectedness is crucial to both Earth's rights and human rights. Lovelock (1979, 1988) visualized interconnectedness when he developed the Gaia hypothesis. Shepard (1973) focuses on humankind's interactions with natural systems and use of natural systems. Sustainability ethics is intimately associated with both the Gaia hypothesis and evolutionary processes, especially those favorable to the continued existence of Homo sapiens on the planet. Preserving the present environment that is so favorable to humans is essential to the preservation of the species. This preservation is both ethical and an act of enlightened self interest. Humankind should always have a compassion for posterity and avoid disrupting evolutionary processes in a way that might endanger the species.

\section{THE PERSISTENCE OF EVOLUTIONARY PROCESSES}

Whatever humankind does, life will probably persist on Earth until the sun dies. Humans may alter evolutionary processes, but they cannot stop them. The previous great extinctions and the recovery from them confirm the resiliency of evolutionary processes. However, paleontological records show that, while evolutionary processes persist, individual species may not. Earth may have 15,000 million years remaining before its end (Dixon \& Adams 2003). The persistence of humans for this remarkable time span is by no means assured. Aided by a group of scientific consultants, Dixon and Adams (2003) speculate on the post-human inhabitants of Earth from 5 to 200 million years from now - following the sixth mass extinction for which humans are not entirely responsible, but to which they make a significant contribution. However, Dixon and Adams (2003) consider the removal of humankind's domineering presence - what might evolutionary processes then produce?

The overall diversity of life forms on Earth has increased despite five successive mass extinctions. The sixth, now in progress, is characterized by humaninfluenced destruction of natural capital. The loss of natural capital will almost certainly have major adverse effects upon both human society and evolutionary processes. The nature of future evolution will be determined by the species and evolutionary processes that survived human influence. In a world without anthropogenic stress, genetic variation and natural selection will decide the fate of life on Earth. Humankind must move from ecological and evolutionary theory to adopting sustainable practices (e.g. Hawken et al. 1999, Ehrlich 2000, Norton 2003).

\section{CONCLUSIONS}

By living sustainably, humankind is more likely to preserve evolutionary processes (and successful incumbent species) that have produced such a favor- 
able environment. Living sustainably will not ensure that humankind will survive indefinitely, but it should prolong human occupancy of Earth. Eliminating unsustainable practices is an obvious first step. The second step is restoring and nurturing natural systems in an actively caring way.

Acknowledgements. K Cairns transcribed the first draft, and D Donald provided editorial assistance.

\section{LITERATURE CITED}

Agyeman J, Bullard RD, Evans B (2003) Just sustainabilities: development in an unequal world. MIT Press, Cambridge, MA

Anderson RC (1998) Mid-course correction. Chelsea Green Publishing Company, White River Junction, VT

Brown LR, Larsen J, Fischlowitz-Roberts B (2002) The Earth policy reader. WW Norton, New York

Cairns J Jr (In press) Sustainable coevolution. Int J Sustain Develop World Ecol

Cairns J Jr, Bidwell J (1996) Discontinuities in technological and natural systems caused by exotic species. Biodiv Conserv 5:1085-1094

Dixon D, Adams J (2003) The future is wild. Firefly Books, Toronto

Eckholm E (2000) Chinese farmers see a new desert erode their way of life. New York Times, 30 July: Late editionfinal, section 1, p1, col3

Ehrlich PR (2000) Human natures: genes, cultures and the human prospect. Island Press, Washington, DC

Ehrlich PR, Ehrlich AH (1990) The population explosion. Simon \& Schuster, New York

Gerber A Jr (2001) Wholeness: on education, Buckminster Fuller, and Tao. Gerber Educational Resources, Kirkland, WA

Hardin G (1999) The ostrich factor. Oxford University Press, Oxford, UK

Harte J, Torn M, Jensen D (1992) The nature and consequences of indirect linkages between climate change and biological diversity. In: Peters R, Lovejoy T (eds) Global warming and biodiversity. Yale University Press, New Haven, CT, pp 325-343

Hawken P, Lovins A, Lovins H (1999) Natural capitalism: creating the next Industrial Revolution. Little, Brown \& Co, New York

Hoffman DJ, Rattner BA, Burton GA Jr, Cairns J Jr (2003) Handbook of ecotoxicology, 2nd edn. Lewis Publishers/ CRC Press, Boca Raton, FL

Editorial responsibility: David R. Orvos, PhD (Editor), Sweet Briar, VA, USA
Kerr RA (1988) No longer willful, Gaia becomes respectable. Science 240:393-395

Lovelock J (1972) Gaia as seen through the atmosphere. Atmospheric Environ 6:579-580

Lovelock J (1979) Gaia: a new look at life on Earth. Oxford University Press, Oxford

Lovelock J (1988) The ages of Gaia. WW Norton, New York

Mayr E (1977) This is biology: the science of the living world. Harvard University Press, Cambridge, MA

Myers N, Knoll AH (eds) (2000) The future of evolution. Proc Nat Acad Sci 98(10):5389-5479

National Academy of Engineering (1996) Engineering within ecological restraints. National Academy Press, Washington, DC

National Academy of Engineering (1997) Technological trajectories and the human environment. National Academy Press, Washington, DC

National Academy of Sciences (2000) The future of evolution, Myers N, Knoll AH (ed). Proc Nat Acad Sci 98(10): 5389-5479

National Research Council (1992) Restoration of aquatic ecosystems: science, technology and public policy. National Academy Press, Washington, DC

National Research Council (2000) Ecological indicators for the nation. National Academy Press, Washington, DC

Norton BG (2003) Searching for sustainability. Cambridge University Press, Cambridge, UK

Odum EP (1997) Ecology. Sinauer Associates, Sunderland, MA

Peacock D (1990) Grizzly years: in search of the American wilderness. Henry Holt, New York

Postal SA, Vickers JR (2004) Boosting water productivity. In: Worldwatch Institute, State of the world. WW Norton, New York, p 46-65

Raup DM (1991) Extinction: bad genes or bad luck. WW Norton, New York

Shepard P (1973) The tender carnivore and the sacred game. Charles Scribner's Sons, New York

Templeton AR, Robertson RJ, Brisson J, Strasburg J (2001) Disrupting evolutionary processes: the effect of habitat fragmentation in the Missouri Ozarks. Proc Nat Acad Sci 98(10):5426-5432

Tickner JA (2003) Environmental science and preventive public policy. Island Press, Washington, DC

Wackernagel M, Rees W (1996) Our ecological footprint. New Society Publishers, Gabriola Island, British Columbia

Wilson EO (1992) The diversity of life. Harvard University Press, Cambridge, MA

Worldwatch Institute (2003a) State of the world. WW Norton, New York

Worldwatch Institute (2003b) Vital signs 2003. WW Norton, New York

Submitted: March 17, 2004; Accepted: June 17, 2004

Proofs received from author(s): August 4, 2004

Published on the web: August 5, 2004 